\title{
TAX AVOIDANCE AND THE DEADWEIGHT LOSS OF THE INCOME TAX
}

\author{
Martin Feldstein
}

Working Paper No. 5055

\section{NATIONAL BUREAU OF ECONOMIC RESEARCH 1050 Massachusetts Avenue Cambridge, MA 02138 March 1995}

Professor of Economics, Harvard University, and President of the National Bureau of Economic Research. I am grateful to Daniel Feenberg for the TAXSIM estimates in section 6 and to him, Jim Hines, Jeff Liebman and other members of the Harvard-MIT Public Economics Seminar for comments on an earlier draft. This paper is part of NBER's research program in Public Economics. Any opinions expressed are those of the author and not those of the National Bureau of Economic Research.

(C) 1995 by Martin Feldstein. All rights reserved. Short sections of text, not to exceed two paragraphs, may be quoted without explicit permission provided that full credit, including $\odot$ notice, is given to the source. 


\title{
TAX AVOIDANCE AND THE \\ DEADWEIGHT LOSS OF THE \\ INCOME TAX
}

\begin{abstract}
The traditional method of analyzing the distorting effects of the income tax greatly underestimates its total deadweight loss as well as the incremental deadweight loss of an increase in income tax rates. Deadweight losses are substantially greater than these conventional estimates because the traditional framework ignores the effect of higher income tax rates on tax avoidance through changes in the form of compensation (e.g., employer paid health insurance) and through changes in the patterns of consumption (e.g., owner occupied housing). The deadweight loss due to the increased use of exclusions and deductions is easily calculated. Because the relative prices of leisure, excludable income, and deductible consumption are fixed, all of these can be treated as a single Hicksian composite good. The compensated change in taxable income induced by changes in tax rates therefore provides all of the information that is needed to evaluate the deadweight loss of the income tax.

These estimates using TAXSIM calibrated to 1994 imply that the deadweight loss per dollar of revenue of using the income tax rather than a lump sum tax is more than twelve times as large as Harberger's classic estimate. A marginal increase in tax revenue achieved by a proportional rise in all personal income tax rates involves a deadweight loss of nearly two dollars per incremental dollar of revenue. Repealing the 1993 increase in tax rates for high income taxpayers would reduce the deadweight loss of the tax system by $\$ 24$ billion while actually increasing tax revenue.
\end{abstract}

Martin Feldstein

National Bureau of Economic Research

1050 Massachusetts Avenue

Cambridge, MA 02138 


\section{Tax Avoidance and the Deadweight Loss of the Income Tax}

\section{Martin Feldstein*}

The traditional method of analyzing the distorting effects of the income tax greatly underestimates its total deadweight loss as well as the incremental deadweight loss of an increase in income tax rates. Ever since Harberger's classic 1964 paper, economists have focused on the effects of the income tax on the supply of labor and the rate of capital accumulation. The relatively low estimated elasticities of labor supply and of saving have led analysts to calculate a correspondingly small deadweight loss of the income tax. In Harberger's own analysis, the deadweight loss of using a tax on labor income instead of a lump sum tax was only about 2.5 percent of the revenue raised (Harberger, 1964). ${ }^{1}$

The actual deadweight losses are substantially greater than these conventional estimates because the traditional framework ignores the effect of higher income tax rates on tax avoidance through changes in the form of compensation (e.g., employer paid health insurance) and through changes in the patterns of consumption (e.g., owner occupied housing). The present paper shows that when these forms of tax avoidance are taken into account, the deadweight losses of the

${ }^{1}$ More recent analyses using this same framework include Auerbach (1985), Ballard et al (1985), Browning (1987), Hausman (1981, 1985), and Stuart (1984). Even within this framework, existing analyses may underestimate the deadweight loss because they define the nature of the labor supply response too narrowly (in terms of just hours and participation) and therefore understate the magnitude of the labor supply elasticity; see Feldstein (1995).

*Professor of Economics, Harvard University, and President of the National Bureau of Economic Research. I am grateful to Daniel Feenberg for the TAXSIM estimates in section 6 and to him, Jim Hines, Jeff Liebman and other members of the Harvard-MIT Public Economics Seminar for comments on an earlier draft. 
income tax and of changes in income tax rates are more than ten times as large as the traditional Harberger calculations imply.

The deadweight loss due to the increased use of exclusions and deductions is easily calculated even when the exclusions cannot be explicitly identified (e.g., improved working conditions.) The key to the calculation is recognizing that the income tax does not change the relative prices of leisure and of the tax-favored forms of consumption that give rise to exclusions and deductions. Because the relative prices of leisure, excludable income, and deductible consumption are fixed, all of these can be treated as a single Hicksian composite good. The analysis in this paper shows that even though the magnitude of the exclusions cannot be measured directly, the compensated change in taxable income induced by changes in tax rates provides all of the information that is needed to evaluate the deadweight loss of the income tax. ${ }^{2}$

The first section of this paper presents a formal analysis that incorporates tax avoidance into the measurement of the deadweight loss of the income tax. Section two reviews evidence on the magnitude of the key elasticity. The third section then presents a calculation of the deadweight loss of the personal income tax as a whole while sections 4 and 5 analyze the incremental deadweight losses caused by proportional and progressive increases in the existing income tax. To show the structure of these calculations in the most transparent way, the calculations of section 3 and 4 use published tax return data that aggregates tax revenue by

${ }^{2}$ Tax avoidance through deductible spending and excludable income is very different from illegal tax evasion because evasion generally reduces spendable income in a nonlinear way, i.e., it is not part of a Hicksian compensated good. See Slemrod (1994) for a very interesting discussion of illegal evasion in this context. Triest (1992) incorporates deductible expenses in a model of labor supply but does not analyze the welfare implications or note that the deadweight loss depends on changes in taxable income rather than changes in labor supply. 
adjusted gross income class. Although using these aggregated data has the advantage of keeping the calculations relatively transparent, the results are very rough approximations that cannot reflect the dispersion of individual marginal tax rates, the nonlinearities of the income tax schedule, the full complexities of the tax law, and the effects of changes in progressivity. The calculations are therefore repeated using the NBER's microeconomic TAXSIM model and the results are presented in section 6 . The seventh section discusses the issue of saving and deferred consumption that is neglected in the earlier parts of the paper. There is a brief concluding section that discusses some of the implications of this work and directions for further analysis.

\section{Tax Avoidance and Deadweight Loss}

The traditional Harberger analysis of the deadweight loss of the income tax specifies the individual's decision problem as a choice between leisure (L) and consumption (C) subject to a budget constraint in which consumption equals labor earnings minus the tax on those earnings: ${ }^{3}$

(1) $\max U(L, C) \quad$ subject to $C=(1-t) w(1-L)$

where $t$ is the proportional rate of income tax and $w$ is the individual's pretax wage rate.

In reality, the individual's income tax liability is not based on total labor income. Some forms of compensation are excluded in the calculation of taxable income even though they enter the individual's utility function (e.g., health benefits) and some forms of consumption are deducted by taxpayers (e.g., mortgage interest) who use the itemized deduction method of calculating taxable income. If we denote the exclusions by $E$ and the deductions by $D$, the

${ }^{3}$ I return below to the issue of saving and deferred consumption. DWL.9 Feb20 
individual's decision problem can be written:

$$
\max U=U(L, C, E, D)
$$

subject to the budget constraint

$$
C=(1-t)[w(1-L)-E-D]
$$

where $\mathrm{C}$ now refers to all general consumption that is not tax-favored through exclusion or deduction and $w(1-L)-E-D$ is taxable income (TI) .

An indication of the order of magnitude of the exclusions and deductions is suggested by the Treasury Department's estimates of tax expenditures in the personal income tax. These tax expenditures are defined as the revenue losses that result from reductions in taxable income due to certain exclusions and deductions. For 1993, the Treasury estimates that the total of all such individual income tax revenue losses is $\$ 388$ billion. ${ }^{4}$ This estimated revenue loss corresponds to deductions and exclusions that are approximately four times larger, i.e., larger by a factor equal to the inverse of the marginal tax rate, or approximately $\$ 1500$ billion. To put this number in perspective, $\$ 1500$ billion is more than 60 percent of the estimated taxable income for 1993. Even this large amount understates the complete sum of exclusions and deductions since the official tax expenditure list does not include a wide range of behavior that reduces taxable income, e.g., the choice of more pleasant working conditions (larger offices, better furniture, air conditioning, location, etc.) instead of higher cash income. ${ }^{5}$

${ }^{4}$ The largest tax-expenditure for an exclusion is the $\$ 51$ billion for employer contributions to health insurance plans. The largest tax expenditure for a deduction is the $\$ 51$ billion for mortgage interest deductions.

${ }^{5}$ There is also the issue of how aspects of the labor-leisure choice like occupation and effort should be counted. I return to this in the concluding section. 
Since the budget constraint of equation 3 can be rewritten as

$$
(1+\tau) C=w-w L-E-D
$$

where $1+\tau=(1-t)^{-1}$, it is clear that the income tax is equivalent to an excise tax on ordinary consumption (i.e., on consumption that is not tax favored) ${ }^{6}$ The income tax therefore changes the relative prices of leisure and ordinary (i.e., not tax favored) consumption, raising the price of ordinary consumption by a factor of $1+\tau$ (or, equivalently, reducing the price of leisure in terms of foregone ordinary consumption from w per unit of leisure to (1-t) w ), but does not change the relative prices of leisure, excludable compensation and deductible consumption. The key conclusion that the relative prices of $\mathrm{L}, \mathrm{E}$ and $\mathrm{D}$ remain unchanged is unaffected if the proportional income tax of equation 3 is replaced by a linear but not proportional tax or by a nonlinear income tax.

The deadweight loss of the income tax can therefore be evaluated as the deadweight loss of an excise tax on ordinary consumption at rate $\tau$. Measuring the change in the deadweight loss that would result from a change in the income tax therefore only requires estimating the change in ordinary consumption that the tax change would induce. More precisely, because the equivalent excise tax applies only to $\mathrm{C}$ as a whole and no taxes distort the relative prices of $\mathrm{L}, \mathrm{E}$ and $\mathrm{D}$, it is not necessary to know the utility substitution elasticities among C, L, E and D in order to measure the deadweight loss of the tax. To see this explicitly, note that the traditional Hicks-Harberger measure of deadweight loss due to price distortions is $0.5 \Sigma \Sigma S_{i j} d_{p_{i}} d p_{j}$, where $S_{i j}$ is the compensated substitution term between goods $i$ and $j$ and $d p_{i}$ is the change in the price

${ }^{6}$ Recall that the analysis now excludes saving and deferred consumption. DWL.9 Feb20 
of good i. If ordinary consumption, $C$, is the first good, equation 4 implies that $d p_{1}=d \tau$ and that $d p_{j}=0$ for $j=2,3$ and 4 . The deadweight loss therefore collapses to $0.5 S_{11}\left(d p_{1}\right)^{2}$. The text that follows shows that this is equivalent in the current case to the product of the elasticity of taxable income with respect to one minus the tax rate and the square of the tax rate. ${ }^{7}$

The calculation of the deadweight loss of the income tax is illustrated with the help of Figure 1. The DD curve is the compensated demand for ordinary consumption relative to

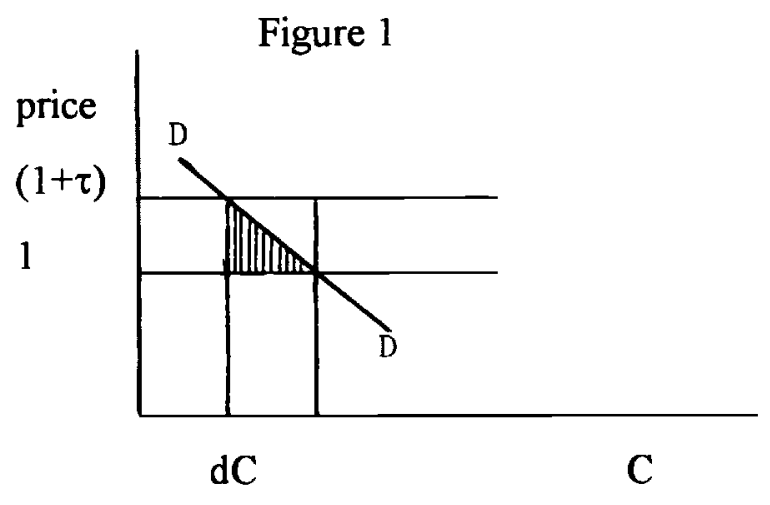

the alternatives of leisure and tax-favored consumption. The excise tax equivalent of the income tax raises the price of ordinary consumption from 1 to $1+\tau$. The deadweight loss is the shaded area equal to $0.5 \tau \mathrm{dC}$. Thus

$$
\begin{aligned}
\text { DWL } & =-0.5 \tau \mathrm{dC} \\
& =-0.5 \tau[\mathrm{d} \mathrm{C} / \mathrm{d}(1+\tau)] \mathrm{d} \tau \\
& =-0.5(\tau /(1+\tau))[(1+\tau) / \mathrm{C}][\mathrm{d} \mathrm{C} / \mathrm{d}(1+\tau)] \tau \mathrm{C} \\
& =-0.5(\tau /(1+\tau)) \varepsilon_{\mathrm{C}} \tau \mathrm{C}
\end{aligned}
$$

${ }^{7}$ In contrast to measuring the deadweight loss of existing tax structures, designing optimal excise taxes or subsidies for a subset of the goods would of course require knowledge of the elasticities of substitution.

DWL.9 Feb20 
Note that $(1+\tau)^{-1}=(1-t)$ implies that $(\tau /(1+\tau))=t$ and $\tau=t /(1-t)$. Equation 5 therefore implies

$$
\mathrm{DWL}=-0.5 \mathrm{t}^{2} \varepsilon_{\mathrm{C}} \mathrm{C} /(1-\mathrm{t})
$$

In the remainder of this section I show that this can be stated in terms of the elasticity of taxable income with respect to the net of tax share. ${ }^{8}$ More specifically, I now show that equation 6 is equivalent to

$$
\mathrm{DWL}=0.5 \mathrm{t}^{2}(1-\mathrm{t})^{-1} \varepsilon_{\mathrm{T}} \mathrm{TI},
$$

the traditional Harberger-Browning formula (Harberger, 1964; Browning, 1987) for the deadweight loss of a tax system but with the usual compensated labor supply elasticity replaced by the compensated elasticity of taxable income with respect to the net-of-tax share $\left(\varepsilon_{\mathrm{T}}\right)$ and with labor income replaced by taxable income (i.e., TI, the labor income net of deductions and exclusions) ${ }^{9}$

The notion of a compensated elasticity of TI with respect to the net of tax share first needs some further explanation. An increase in the net of tax share of money wages that the taxpayer can keep has both an income effect and a substitution effect. The compensated or substitution effect of an increase in 1-t is to induce the taxpayer to consume less leisure and less

\footnotetext{
${ }^{8}$ In the special case in which there is no excludable income or deductible consumption, this analysis is equivalent to the traditional deadweight loss calculation since changes in the demand for ordinary consumption are equivalent under those conditions to changes in labor supply.
}

${ }^{9}$ Note that this measures the deadweight loss due to changes in the income tax rate and not the deadweight loss that results from changes in the list of deductions and exclusions or other changes in the structure of the income tax.

DWL.9 Feb20 
of the tax favored forms of consumption and therefore more of the ordinary consumption. The compensated effect of an increase in 1-t is therefore to increase TI. However, a rise in the after tax share causes an increase in disposble income at the intial levels of leisure and tax favored consumption. This in turn causes the individual to want more leisure and more of the tax favored consumption, i.e, less taxable income. This response to the increase in disposable income is the income effect of the change in the net of tax share. If dy is the increase in disposable income with no behavioral response, the income effect is the decrease in taxable income at a rate equal to $\mathrm{dTL} / \mathrm{dy}$. If there were no excludable income or deductible consumption, $-\mathrm{dTI} / \mathrm{dy}=\mathrm{wdL} / \mathrm{dy}>$ 0 , the value of the increase in leisure demanded per incremental dollar of lump sum income. More generally, an increase in exogenous income will induce an increase in excludable income (i.e., more fringe benefits) and an increase in deductible consumption. Thus $d \mathrm{TI} / \mathrm{dy}=\mathrm{d}[\mathrm{w}-$ $w L-E-D] / d y<0$.

With this concept in mind, note that equations 6 and 7 are equivalent if $-\varepsilon_{\mathrm{C}} \mathrm{C}=\varepsilon_{\mathrm{T}}$ TI.

Since $\varepsilon_{\mathrm{C}}=(1+\tau) \mathrm{C}^{-1}\{\mathrm{~d} \mathrm{C} / \mathrm{d}(1+\tau)\}_{\mathrm{COMP}}$ and $(1+\tau)=(1-\mathrm{t})^{-1}$, it follows that $\varepsilon_{\mathrm{C}}=-(1-\mathrm{t}) \mathrm{C}^{-1}\{\mathrm{~d} \mathrm{C} / \mathrm{d}(1-\mathrm{t})\}_{\mathrm{COMP}}$. By definition, $\varepsilon_{\mathrm{T}}=(1-\mathrm{t})(\mathrm{TI})^{-1}\{\mathrm{~d} \mathrm{TL} / \mathrm{d}(1-\mathrm{t})\}_{\mathrm{COMP}}$.

Since the uncompensated change in TI with respect to a tax change differs from the change in consumption only by the amount of the tax paid, the compensated effects are equal: $\{\mathrm{dC} / \mathrm{d}(1-\mathrm{t})\}_{\mathrm{COMP}}=\{\mathrm{dTI} / \mathrm{d}(1-\mathrm{t})\}_{\mathrm{COMP}}$. It follows that $-\mathrm{C} \varepsilon_{\mathrm{C}}=(1-\mathrm{t})\{\mathrm{d} \mathrm{C} / \mathrm{d}(1-\mathrm{t})\}_{\mathrm{COMP}}=$ $(1-\mathrm{t})\{\mathrm{dTI} / \mathrm{d}(1-\mathrm{t})\}_{\mathrm{COMP}}=\mathrm{TI} \varepsilon_{\mathrm{T}}$. This establishes the equivalence of equations 6 and 7 as measures of the deadweight loss 


\section{The Elasticity of Taxable Income with Respect to the Net of Tax Share}

In an earlier paper (Feldstein 1993), I estimated the value of $\varepsilon_{\mathrm{T}}$ on the basis of taxpayers' responses to the 1986 tax rate reductions. That analysis used a panel of individual tax returns created by the Treasury Department that allows a comparison of each taxpayer's return for 1985 with the same taxpayer's return for 1988. I focused on married taxpayers who were under age 65 in 1988. Taxable income was adjusted for changes in the law in 1986 and exclude the portion of taxable income due to capital gains and to gross partnership losses. These adjustments permit the estimated change in taxable income to reflect the change in marginal tax rates rather than other changes in tax rules. ${ }^{10}$

The 1986 tax reforms were designed to be revenue neutral and distributionally neutral. To the extent that this was achieved, the behavioral response can be used directly as an estimate of $\varepsilon_{\mathrm{T}}$, the revenue neutral compensated elasticity of taxable income with respect to the net of $\operatorname{tax}$ share. ${ }^{11}$

To estimate the elasticity, taxpayers were grouped according to their 1985 marginal tax rate and the adjusted taxable incomes were compared for 1988 and 1985. Comparison of the changes in taxable incomes to the changes in the net of tax shares in different marginal tax rate

${ }^{10}$ The sample also excluded taxpayers who created a subchapter $\mathrm{S}$ corporation between 1985 and 1988. The specific reasons for excluding gross partnership losses and taxpayers who created Subchapter S corporations are discussed in Feldstein(1993).

${ }^{11}$ Determining the extent to which the tax legislation was revenue neutral and distributionally neutral is complicated by the uncertain incidence of the corporate income tax changes that were part of the 1986 tax reform act. 
groups provides alternative estimates of the elasticity of taxable income with respect to the net of tax share. This differences-in-differences approach avoids the identification problems of traditional regression estimates.

An example will indicate the nature of the differences-in-differences calculation.

Taxpayers who were in the highest marginal tax rate class in 1985 (with marginal tax rates of 49 and 50 percent) had average marginal tax rates of approximately 28 percent in 1988, a 42.2 percent rise in the net of tax share. Taxpayers in the next group, with marginal tax rates of 42 percent to 45 percent in 1985 , experienced a 25.6 percent rise in the net of tax share. The corresponding increases in the adjusted taxable income for the two groups were 44.8 percent and 20.3 percent. The comparison of changes in $\mathrm{TI}$ and in 1-t implies an elasticity of 1.48 . Similar comparisons between the taxpayers in the highest 1985 marginal tax rate groups and those in the medium marginal tax rate range (with 1985 marginal tax rates of 22 percent to 38 percent) implies an elasticity of 1.25 . Finally a comparison of the TI changes for those who started with marginal tax rates of 42 to 45 percent and those who started with marginal tax rates of 22 percent to 38 percent implies an elasticity of 1.04 . The simple average of these three elasticities was thus 1.26 .

Gerald Auten and Robert Carroll (1994) of the Treasury Department's Office of Tax Analysis subsequently reestimated the same elasticity using the much larger panel of tax returns for 1985 and 1989 that is available inside the Treasury but not available for outside use. Their sample of more than 14,000 returns includes more than 5,000 taxpayers with 1985 marginal tax rates of 50 percent or higher. They report an estimated elasticity of 1.33 with a standard error of 
The Feldstein (1993) and Auten-Carroll (1994) estimates are broadly consistent with earlier elasticity estimates by Lindsey (1987) based on comparing cross-sections of ranked taxpayers before and after the 1981 tax rate reductions and with Navratil's (1994) estimates based on panel data of taxable incomes for individuals before and after the rate reductions. Lindsey summarized his research findings as indicating an elasticity of taxable income with respect to the net of tax share of between 1.6 and 1.8 while Navratil found an elasticity of 0.84 (standard error 0.13 ). The Lindsey estimates may be biased up by his use of "synthetic panels" since, as Navratil has shown, the ranking of taxpayers does in fact change over time. But the Lindsey and Navratil estimates are also subject to a downward bias as an estimate of the compensated elasticity since the 1981 tax changes, unlike those of 1986 , were intended to reduce tax liabilities as well as tax rates.

It is important to emphasize that the elasticity of TI with respect to the net of tax share is conceptually very different from the more familiar elasticities of labor supply with respect to the net of tax share. A taxpayer can respond to a higher marginal tax rate not only by working fewer hours (the traditional labor supply response) but also in a variety of other ways that reduce taxable income. These include working less hard per hour (including not only the amount of effort per hour but also such dimensions as the amount of travel, employee location,

${ }^{12}$ Alternative weightings of observations produce elasticity estimates of 0.86 (with a standard error of 0.20 ) and 1.88 (with a standard error of 0.33 ). The authors caution that the lower value (which is obtained when the observations are weighed by 1985 incomes) is likely to be biased if high 1985 incomes correspond to high transitory income in that year. 
responsibility accepted, etc.), receiving compensation in ways other than cash that are excluded from taxable income (fringe benefits, office amenities, first class travel, corporate health and fitness facilities, subsidized corporate day care for children, etc.), and spending money in ways that are deductible in the calculation of taxable income. ${ }^{13}$

It is not surprising therefore that the estimate of $\varepsilon_{\mathrm{T}}$ is substantially larger than the traditional estimates of the compensated labor supply elasticity. The much broader range of response implied by the change in TI than by the change in labor supply (or leisure) implies a substantially larger deadweight loss. ${ }^{14}$

\section{The Deadweight Loss of the Income Tax}

Before using the detailed TAXSIM model based on individual tax returns to estimate the deadweight loss of the income tax and of marginal changes in the income tax, it is useful to

${ }^{13}$ Some reductions in taxable income of the individual represent a transfer of taxable income from the individual to the corporate employer. Deferred compensation is a very clear example of this. Such intertemporal aspects are beyond the scope of this paper but are reflected in the empirically estimated elasticity of TI with respect to the 1-t tax share.

${ }^{14}$ The estimated elasticity $\varepsilon_{\mathrm{T}}$, as reported in Feldstein (1993) and in Auten and Carroll (1994), is based on the experience of taxpayers with 1985 marginal tax rates over 20 percent. It is not clear a priori whether the elasticity would be lower or higher for taxpayers with lower marginal tax rates and lower incomes. Because such taxpayers may have less discretion about the form of compensation and are less likely to itemize deductions, the elasticity could be lower. However, even a small change in wages could imply a proportionately very large change in taxable income for lower income taxpayers; for example, a couple with wage income of $\$ 25,000$ and two children that uses the standard deduction now has a taxable income of less than $\$ 9,000$ so a five percent decrease in earnings translates into a 14 percent decline in taxable income. The analysis of a proportional change in all tax rates, reported in section 6 , shows that the revenue and dead loss effects are almost unchanged if it is assumed that lower income taxpayers (the 31 million taxpayers with adjusted gross income less than $\$ 25,000$ ) do not respond at all to changes in marginal tax rates. 
present simpler and more transparent calculations based on aggregated data. This section calculates the deadweight loss of using the income tax instead of a lump sum tax with the same revenue. Section 4 then estimates the deadweight loss of a 10 percent rise in all income tax rates and the additional revenue that would result from that increase.

Equation 7 noted that DWL $=0.5 \varepsilon_{\mathrm{T}} \mathrm{t}^{2}(1-\mathrm{t})^{-1} \mathrm{TI}$ where $\varepsilon_{\mathrm{T}}$ is the revenue-neutral compensated elasticity of taxable income (TI) with respect to the marginal net of tax share (1-t). To be conservative in the calculations that follow, I use $\varepsilon_{\mathrm{T}}=1.04$, the lowest of the elasticity estimates reported in Feldstein (1993). The Treasury Department reports that 1992 taxable income (the most recent year for which such data are available) was $\$ 2,396$ billion and that the income tax paid on this taxable income was $\$ 476$ billion, implying an average tax rate of 0.20 (U.S. Department of Treasury, 1994b) . Using this implied average tax rate instead of the marginal tax rate substantially understates the deadweight loss ${ }^{15}$ Even so, the deadweight loss of the income tax is DWL $=.5(1.04)(.2)^{2}(1.25) 2396=\$ 62.3$ billion. This is 13.1 percent of personal income tax revenue, about five times as high as the original Harberger estimate.

Because of the progressivity of the income tax, this $\$ 62$ billion is a substantial underestimate of the deadweight loss. As a first approximation, the weighted average of the marginal tax rates estimated from the Treasury's published data (Department of Treasury, 1994a,

\footnotetext{
${ }^{15}$ This also ignores the social security payroll tax and the state income taxes, both of which raise the marginal tax rate for most taxpayers. I return to the Social Security payroll tax later in the current section. All of the current calculations, including those using the TAXSIM model, ignore the added distortion due to the state income taxes.
}

DWL.9 Feb20 
p. 25) implies an average marginal tax rate of $0.24{ }^{16}$ Substituting this into the calculation implies that DWL $=.5(1.04)(.24)^{2}(1.32) 2396=\$ 95$ billion. This deadweight loss estimate is thus 20 percent of the revenue raised by the personal income tax. It implies a relative deadweight loss that is eight times as large as the original Harberger estimate. ${ }^{17}$

These calculations have ignored the additional marginal tax rate implied by the Social Security payroll tax. Because the personal income tax rates are added to these Social Security payroll taxes, the distortion and deadweight loss of the personal income tax is greater than it would be if there were no Social Security payroll tax.

More specifically, the current 15.3 percent rate consists of two basic parts: the 2.9 percent Medicare health insurance component (HI) that is not related to the individual's future benefits and the 12.4 percent part that pays for retirement and disability benefits (OASDI) that are related to the individual taxpayer's past incomes. Although the 2.9 percent part is an unambiguous addition to the marginal tax rate, the 12.4 percent part must be adjusted for the

\footnotetext{
${ }^{16}$ The published data indicate the Treasury's preliminary estimate of the number of tax returns and the amount of taxable income in 14 adjusted gross income classes. I calculated the average taxable income per return in each class, found the marginal tax rate corresponding to that income for a joint filer, and then took the weighted average of these marginal tax rates. The result is a weighted average marginal tax rate of 0.24 .

${ }^{17} \mathrm{~A}$ somewhat better estimate can be obtained with the published data by applying the DWL formula in each of the fourteen adjusted gross income classes reported by the Treasury and then aggregating; the implied total deadweight loss calculated in this way is $\$ 102$ billion. I will continue to use the average of the marginal rates until the more accurate microeconomic estimates are developed in section six. Estimates based on the 1992 tax schedules also underestimate the deadweight loss implied by the current tax rates because the 1993 tax legislation raised the top marginal tax rate from 31 percent to more than 42 percent; the microeconomic estimates of section six are based on these post-1993 tax rates.
} 
present actuarial value of the future benefits that are related to the OASDI tax base. Feldstein and Samwick (1993) provide detailed estimates of the net present value of future retirement benefits for individuals by sex and dependency status (e.g., a male without a Social Security dependent spouse or a female dependent spouse) that will be used in the microeconomic TAXSIM analysis of the next section. For now, I will approximate the marginal burden of the payroll tax as the sum of the health insurance portion (.029) and one-third of the retirement portion $(0.041)^{18}$ or a total payroll tax of $0.07 .{ }^{19}$

To incorporate this tax into the overall marginal tax rate calculation, it is necessary to recognize that the half of the tax that is formally paid by the employer is excluded from taxable income. The effective tax rate as a fraction of the gross wage is therefore the sum of the payroll tax rate and the personal income tax rate divided by one plus half of the marginal gross payroll tax rate: $(0.07+0.24) / 1.0765=0.29$. The total DWL is then $0.5(1.04)(.29)^{2}(1.41) 2396=$ $\$ 148$ billion. ${ }^{20}$ This is 23 percent of the combined personal income tax and net social security

${ }^{18}$ The effective marginal tax rate varies by income, age and sex and, among married couples by the division of income between husband and wife. For example, a married couple with husband and wife both age 45 and both working enough to anticipate retirement benefits based on their own incomes would face marginal OASI tax rates of 4.98 percent for the husband and 2.36 for the wife. If the wife would eventually claim benefits based on his income only, the effective net marginal OASI tax rate couple would be -2.13 percent for the husband but 11.2 percent for the wife. The disability portion of the payroll tax was a total 1.2 percent; the present analysis assumes that this is actuarially fair for married women.

19 In 1992, the health insurance portion applied to incomes up to $\$ 130,200$ and the retirement portion applied to incomes up to $\$ 55,500$. I ignore these ceilings (which apply to less than 10 percent of returns) in the current calculations but take them into account in the disaggregated TAXSIM analysis of section 6 .

${ }^{20} \mathrm{This}$ ignores the difference between the tax base for personal income tax and the tax base for the Social Security payroll tax. The Social Security payroll tax is levied only on wage and salary DWL.9 Feb20 
tax revenue. ${ }^{21}$

The deadweight loss of using the existing (1992) personal income tax rates instead of a lump sum tax, given that there is a 7 percent net Social Security payroll tax, can be approximated as the difference between the deadweight losses with a marginal tax rate of 0.29 and the deadweight loss with a marginal tax rate of $0.07 / 1.0765=0.065$ or $\triangle \mathrm{DWL}=0.5(1.04)$ $\left\{(.29)^{2}-(.065)^{2}\right\}(1.41) 2396=\$ 141$ billion or 30 percent of the revenue raised by the personal income tax, about twelve times the original Harberger estimate.

\section{The Deadweight Loss of a Proportional Increase in Income Tax Rates}

Although it is interesting to compare the deadweight loss of the personal income tax as a whole relative to an equal yield lump sum tax, practical tax policy is about incremental changes in tax rates. The deadweight loss of such incremental changes is easily calculated in the same way as the total DWL of the previous section. In considering an incremental tax change it is also interesting to estimate the impact on revenue and to calculate the resulting deadweight loss per dollar of additional revenue.

Consider first the simplified case in which the only tax based on personal income is the personal income tax, i.e., in which the Social Security payroll tax is ignored. A 10 percent

income up to that limits stated above. Since total wage and salary income that is reported as part of adjusted gross income was $\$ 2,806$ billion in 1992 , or 17 percent greater than taxable income, limiting the calculation to taxable income will bias down the estimate of the DWL.

${ }^{21}$ This combined net tax is approximated here as the sum of the personal income tax and 0.07 times taxable income. 
increase in all personal income tax rates would raise the deadweight loss from $\mathrm{DWL}_{1}=$ $5 \mathrm{t}_{1}^{2}\left(1-\mathrm{t}_{1}\right)^{-1} \varepsilon_{\mathrm{T}}$ TI to $\mathrm{DWL}_{2}=.5\left(1.1 \mathrm{t}_{1}\right)^{2}\left(1-\mathrm{t}_{1}\right)^{-1} \varepsilon_{\mathrm{T}} \mathrm{TI}$. The increase in the DWL is thus $\Delta \mathrm{DWL}=$ $.5(.21) \mathrm{t}_{1}^{2}\left(1-\mathrm{t}_{1}\right)^{-1} \varepsilon_{\mathrm{T}}$ TI. In short, a 10 percent rise or fall in all marginal tax rates raises or lowers the initial deadweight loss by 21 percent.

A more realistic calculation must recognize that the personal income tax is not the only tax on personal income and that the Social Security payroll tax increases the marginal tax rate both before and after the increase in the personal income tax rates. The change in the deadweight loss is therefore $\Delta \mathrm{DWL}=.5 \varepsilon_{\mathrm{T}}\left[\left(1.1 \mathrm{t}_{1}+0.07\right)^{2}-\left(\mathrm{t}_{1}+0.07\right)^{2}\right](1.0765)^{-2}\left[\left(1-\left(\mathrm{t}_{1}+0.07\right) /(1.0765)\right]^{-1}\right.$ TI. If the initial marginal income tax rate is $t_{1}=0.24$, the initial DWL is $.061 \mathrm{TI}$ and the increase associated with a 10 percent rise in marginal tax rates is $.0097 \mathrm{TI}$, a 15.9 percent rise in the deadweight loss. With TI $=\$ 2396$ billion in 1992 , the deadweight loss of the 10 percent rise in rates is $\$ 23$ billion.

It is particularly interesting to calculate the tax inefficiency ratio, i.e., the ratio of the increased deadweight loss to the incremental revenue. For this purpose, the changes in personal income tax revenue and payroll tax revenue must be calculated separately since the induced change in overall taxable income is not the same as the change in the labor income that is subject to the payroll tax. Total revenue will be written as $\mathrm{REV}=\mathrm{REV}^{\mathrm{PTT}}+\mathrm{REV}^{\mathrm{SSH}}$ where $\mathrm{REV}^{\mathrm{PTT}}$ is the personal income tax revenue and $\mathrm{REV}^{\mathrm{SSH}}$ is the Social Security and $\mathrm{HI}$ payroll tax revenue. The tax base for the personal income tax will continue to be denoted TI while the tax base for the payroll tax will be denoted $\mathrm{W}$ (for wage income). The marginal personal income tax rate is $\mathrm{t}^{\mathrm{PTT}}$ and the corresponding average tax rate is $\mathrm{t}_{\mathrm{a}}^{\mathrm{PTT}}$. If the payroll tax rate (net of the present value of 
future benefits that result from paying that tax) is $\mathrm{t}^{\mathrm{sSH}}$, the overall marginal tax rate that affects behavior is $\mathrm{t}=\mathrm{t}^{\mathrm{PTT}}+\mathrm{t}^{\mathrm{SSH}}$. The payroll tax revenue depends on the gross employer-employee payroll tax $\mathbf{t}^{\mathrm{SSH}-\mathrm{G}}$

Consider first the revenue from the personal income tax. If taxpayers do not change their behavior in response to an increase in marginal tax rates, an $\mathrm{x}$ percent increase in all marginal tax rates would increase the tax paid by $x$ percent (i.e., by the product of taxable income and $x$ percent of the initial average tax rate ( $t_{a}^{\text {PIT }}$ ). More generally, however, this amount will be reduced by the product of the marginal tax rate and the induced decline in taxable income. Thus, when the only tax change is a change in marginal tax rates (i.e., there is no change in tax rules, allowable deductions, etc.), the incremental personal income tax revenue ( $\left.\mathrm{REV}^{\mathrm{PTT}}\right)$ can be approximated for each taxpayer by:

$$
\mathrm{d} \mathrm{REV}^{\mathrm{PIT}}=\mathrm{TI} \mathrm{dt}_{\mathrm{a}}^{\mathrm{PIT}}+\mathrm{t}^{\mathrm{PTT}} \mathrm{dTI}
$$

where $\mathrm{TI}$ is the initial level of taxable income, $\mathrm{dt}_{\mathrm{a}}^{\mathrm{PIT}}$ is the change in the average personal income tax rate expressed as a fraction of taxable income and $\mathrm{d}$ TI can be derived from

$$
d \mathrm{TI} / \mathrm{d}(1-\mathrm{t})=\{\mathrm{dTI} / \mathrm{d}(1-\mathrm{t})\}_{\mathrm{COMP}}+(\mathrm{d} \mathrm{TI} / \mathrm{dy})(\mathrm{dy} / \mathrm{d}(1-\mathrm{t}))
$$

or

$$
\mathrm{d} T \mathrm{TI}=\varepsilon_{\mathrm{T}} \mathrm{TI}(1-\mathrm{t})^{-1} \mathrm{~d}(1-\mathrm{t})+(\mathrm{d} \mathrm{TI} / \mathrm{dy}) \mathrm{dy}
$$

where dy is the revenue change with no behavioral response: $d y=T I d t_{a}^{P I T}$

The value of $\varepsilon_{\mathrm{T}}$ has already been discussed and will be estimated at 1.04 . To assess $\mathrm{dTI} / \mathrm{dy}$, note that $\mathrm{TI}=\mathrm{w}(1-\mathrm{L})-\mathrm{D}-\mathrm{E}$ implies

$$
d T l / d y=-w d L / d y-d D / d y-d E / d y .
$$


The first of these is the traditional income effect on the demand for leisure; the labor supply literature suggests that $\mathrm{w} d \mathrm{~L} / \mathrm{dy}$ is approximately 0.10 to $0.15{ }^{22}$

The effect of an increase in exogenous income on deductible consumption ( $\mathrm{dD} / \mathrm{dy})$ can be approximated by a regression of itemized deductions on adjusted gross income (AGI) holding constant the marginal tax rate. To focus on those itemized deductions that represent deductible consumption, the measure of deductions used in the regressions excludes income taxes paid to state and local governments and interest deductions other than mortgage deductions (since such nonmortgage interest deductions are now associated with investment activity rather than consumption.) ${ }^{23}$ Table 1 reports these regression coefficients for 1991 based on dividing the population of taxpayers into different marginal tax rate groups and then regressing deductions on AGI within each MTR group. ${ }^{24}$ Since the individual taxpayer's marginal tax rate depends on the extent of that taxpayer's deductions, I use the "first dollar marginal tax rate" as the basis for classification. ${ }^{25}$ These regression estimates imply that taxpayers spend an additional 10.6 cents

22 These estimates are limited to the effect of changes in hours and participation rates and therefore understate the full long-run response of labor supply, including career choice, location, etc.. This restricted definition of labor supply also causes the estimated compensated elasticity to understate the true long-run response.

${ }^{23}$ Even mortgage interest deductions are ambiguous since funds borrowed as mortgages may be used for portfolio investments.

${ }^{24}$ Each regression equation has a constant term and an adjusted gross income variable. The coefficients are estimated by ordinary least squares with the observations weighted by the population weights. The data used in these regressions are the Treasury Department's public use sample of individual tax returns. The regression sample includes both itemizers and nonitemizers. The deduction for nonitemizers is zero.

${ }^{25}$ The first dollar marginal tax rate for each individual tax return is the marginal tax rate at a zero level of itemized deductions. 
on deductible consumption for each extra dollar of income. The amount is somewhat higher (about 15 cents) for taxpayers in the 28 percent tax bracket (i.e., with pre-deduction taxable incomes between $\$ 34,000$ and $\$ 82,000$ ) than for lower income individuals or higher income individuals.

There is unfortunately no satisfactory way to estimate the extent to which excluded compensation changes in response to exogenous income (dE/dy). The largest component of excluded income is now employer paid health insurance which varies relatively little with incom beyond a moderate income threshold. Pension contributions vary with wage and salary income but are not likely to vary with lump sum exogenous income. Other forms of excluded income, ike the quality of the work environment may be more income sensitive. It is only as a guess therefore that I assign a value to $\mathrm{dE} / \mathrm{dy}$ of 0.15 , bringing the total value of $\mathrm{dTI} / \mathrm{dy}$ to $-0.4{ }^{26}$

Combining equations 8 and 10 (with the additional relation that $d y=T I d_{2}$ ) implies:

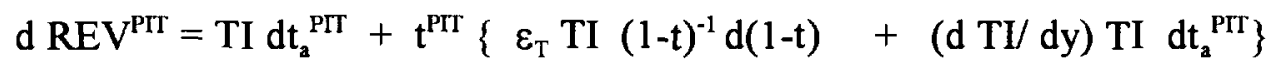

Since the average and marginal personal income tax rates are initially 0.2 and 0.24 , a 10 percent rise in all rates implies $\mathrm{dt}_{\mathrm{a}}{ }^{\mathrm{PrT}}=0.02$ and $\mathrm{dt}^{\mathrm{PrT}}=0.024$. With the addition of the net Social Security taxes, the initial combined marginal tax rate that influences behavior is $0.31 /(1.0765)=$ 0.288 and rises to $0.334 /(1.0765)=0.310$ so that $(1-t)^{-1} d(1-t)=-.022 /(.71)=-.031$. The change in personal income revenue per dollar of incremental taxable income, evaluated at the

\footnotetext{
${ }^{26}$ The analysis assumes that the amount of excluded compensation, like the amount of deductible consumption, does not depend directly on the individual's marginal productivity. This can be true even if the level of the excluded income is chosen by the firm (e.g., the amount of health insurance.)
}

DWL.9 Feb20 
Table 1

The Effects of Income on Itemized Deductions

First Dollar

Marginal

Tax Rate

0.15

0.28

0.31

Weighted

Sum

Regression Coefficient Estimates of Change in Deduction per Dollar of AGI

Mortgage

Interest

0.081

$(0.001$

0.115

$(0.002)$

0.029

$(0.001)$

0.071
Deductions Other than

Interest and State Income Taxes
0.028

$(0.001)$

0.038

$(0.001)$

0.042

$(0.041)$

0.035

Source: Estimates based on 1991 TAXSIM sample. Standard errors are shown in parentheses. The weighted sum is weighted by the adjusted gross income in each marginal tax rate class. 
initial personal income tax rate, is $\mathrm{t}^{\mathrm{PTT}}=0.24$. Using $\mathrm{TI}=\$ 2396$ billion, $\varepsilon_{\mathrm{T}}=1.04$, and $\mathrm{d} \mathrm{TI} / \mathrm{dy}=$ -0.4 , equation 12 implies (in billions of dollars):

$$
\begin{aligned}
& \mathrm{d} \mathrm{REV}^{\mathrm{PTT}}=2396(.02)+.24\{1.04 * 2396 *(-.031)+0.4(2396)(.02)\} \\
& \quad=48+.24\{-77+19\}=\$ 34 \text { billion. }
\end{aligned}
$$

Equation 13 shows that the 10 percent increase in the personal income tax rates would raise personal income tax revenue by $\$ 48$ billion if there were no reduction in taxable income. But since the increase in the total marginal net tax rate from .288 to .310 reduces the net of tax share from .712 to .690 , a decline of 3.1 percent, the compensated elasticity of 1.04 implies a decline in taxable income of $\$ 77$ billion. The income effect of the no-behavioral-response tax rise of $\$ 48$ billion raises taxable income by $\$ 19$ billion as taxpayers consume less leisure and other tax favored consumption. The combined effect is a $\$ 58$ billion decline in taxable income and the net effect on revenue is a decline of .24 ( $\$ 58$ billion) $=\$ 14$ billion. Combining this $\$ 14$ billion revenue loss and the direct revenue gain of $\$ 48$ billion shows that net gain in personal income tax revenue is $\$ 34$ billion.

The increase in the marginal tax rate also reduces the wage income that is taxed by the payroll tax at rate $\mathrm{t}^{\mathrm{SSH}-\mathrm{G}}=0.153$. The sensitivity of wage income to the net-of-tax share is not as large as the sensitivity of overall taxable income since the general taxable income response includes changes in deductions and in the form of investment income that do not affect taxable wage income. The response of wage income is however more than the traditional labor supply effect of changes in participation and hours since it also includes the effect of changes in work effort (broadly defined to include such things as the choice of occupation, location, willingness to accept responsiblity, etc.) and the effect of changes in the mix of taxable wages and DWL.9 Feb20 
nonmonetary compensation (fringe benefits, working conditions, etc that constitute the exclusions, E).

The statistical estimates of the compensated elasticity of taxable income with respect to the net of tax share must therefore be modified to assess changes in taxable wages, W. To be conservative, I will take the compensated elasticity of W with respect to 1-t to be only one-third of the compensated TI elasticity used for the personal income tax revenue and for the deadweight loss calculations. It is also necessary to revise the estimated income effect by omitting the effect on deductions $(\mathrm{dD} / \mathrm{dy})$ so that the change in taxable wages becomes: $\mathrm{dW} / \mathrm{dy}=-\mathrm{wdL} / \mathrm{dy}-\mathrm{dE} / \mathrm{dy}=$ 0.3 .

The change in the payroll tax revenue is, by analogy with equation $8, \mathrm{~d} \mathrm{REV}^{\mathrm{SSII}}=$ $\mathrm{W} \mathrm{dt}{ }^{\mathrm{SSH}-\mathrm{G}}+\mathrm{t}^{\mathrm{SSH}-\mathrm{G}} \mathrm{dW}$. Since the ten percent increase in the personal income tax rates involves no change in the payroll tax rates, $\mathrm{dt}^{\mathrm{SSH}-\mathrm{G}}=0$ and $\mathrm{d} \mathrm{REV}^{\mathrm{SSH}}=\mathrm{t}^{\mathrm{SSH}-\mathrm{G}} \mathrm{dW}$. The total induced change in taxable wages can be written (like equation 10 above for taxable income)

$$
d W=W \varepsilon_{W}(1-t)^{-1} d(1-t)+(d W / d y) d y .
$$

The wage income that was subject to the payroll tax in 1992 was $\mathrm{W}=\$ 2490$ billion. The values of $\mathrm{d}(1-\mathrm{t}) /(1-\mathrm{t})=-0.031$ and $\mathrm{dy}=\$ 48$ billion, derived for equation 13 , are relevant for the payroll tax revenue as well. With $\varepsilon_{\mathrm{W}}=0.35$ and $\mathrm{dW} / \mathrm{dy}=-0.3$, equation 14 implies $\mathrm{dW}=-\$ 12.6$ billion. Applying the gross payroll tax rate of 15.3 percent implies that $\mathrm{d} \mathrm{REV}^{\mathrm{SSH}}=-\$ 1.9$ billion. Combining the incremental personal income tax revenue of $\$ 34$ billion and the reduction in payroll revenue of $\$ 1.9$ billion yields a net revenue increase of approximately $\$ 32$ billion. Comparing the incremental deadweight loss of $\$ 23$ billion and the incremental revenue of $\$ 32$ 
billion implies a tax inefficiency ratio of 72 percent, i.e., there is 72 cents of incremental deadweight loss for every incremental dollar of revenue.

Even this very high measure of tax inefficiency substantially understates the true value because these aggregate calculations do not reflect the distribution of marginal tax rates. Instead of using the published data to improve the approximation, I will use the microeconomic TAXSIM calculations in section 6 which can capture the full nonlinearities of the tax rules. Before turning to the TAXSIM calculations, I will discuss the effect of changes in progressivity on the inefficiency of the tax system.

\section{The Effects of an Increase in Income Tax Progressivity}

An increase in tax progressivity raises the deadweight loss per dollar of tax revenue. This can be seen intuitively by noting that the deadweight loss of the tax depends on the weighted average of the squared marginal tax rates while the revenue depends on the same weighted average of the marginal tax rates themselves. The greater convexity of the more progressive marginal rate schedule raises the mean of the squared marginal rates proportionately more than it raises the mean of the rates themselves.

The current section discusses the effect of increased progressivity by examining the 1993 tax legislation. The top marginal rate of personal income tax was raised from 31 percent to 36 percent for married taxpayers with taxable incomes between $\$ 140,000$ and $\$ 250,000$ and from 31 percent to 39.6 percent for married taxpayers with taxable incomes over $\$ 250,000$. In addition the $\$ 135,000$ income ceiling for the 2.9 percent health insurance payroll tax was 
eliminated, bringing the total marginal tax rates to 38.9 percent ${ }^{27}$ and 42.5 percent from the previous 31 percent.

Because of the nonlinear character of this change, the deadweight loss and the revenue effects cannot be estimated with the aggregate published data but must be calculated with the individual tax returns in the TAXSIM analysis. Before doing so in the next section, it is useful to study at a few representative high income taxpayers to indicate the nature of the calculations that will be performed in the TAXSIM analysis and to see why those calculations imply an extremely high ratio of incremental deadweight loss to incremental revenue.

Consider first a taxpayer with $\$ 180,000$, the median income level among those whose tax rates were increased in 1993. Since the taxpayer is above the maximum taxable income for the Social Security payroll tax, the rise in the marginal income tax rate from $t_{1}=.31$ to $t_{2}=.389$ increased the individual taxpayer's deadweight loss by $\Delta \mathrm{DWL}=.5 \varepsilon_{\mathrm{T}}\left[\mathrm{t}_{2}{ }^{2}-\mathrm{t}_{1}{ }^{2}\right]\left(1-\mathrm{t}_{1}\right)^{-1} \mathrm{TI}$ $=.5(1.04)(.055)(1.45) 180,000=\$ 7461$.

Because the increased personal tax rate applies only to income in excess of $\$ 140,000,{ }^{28}$ equation 8 can no longer be used to calculate the additional revenue. With no behavioral response, i.e. with no change in taxable income, the increased revenue would equal the 7.9

${ }^{27}$ Since half of the 2.9 percent is paid by employers, the marginal tax rate on full pretax income is $38.9 / 1.0145=38.3$ percent. I ignore this distinction in the current section.

${ }^{28}$ This ignores the small additional revenue $(\$ 145)$ associated with the additional HI payroll tax of 2.9 percent on the income between $\$ 135,000$ and $\$ 140,000$. This is taken into account in the microsimulation of section 6 .

DWL.9 Feb20 
percent rate increase on the applicable base between $\$ 140,000$ and $\$ 180,000$ or $\$ 3160{ }^{29}$ However, the 7.9 percent rise in the marginal tax rate reduces the net of tax share from 69 to .611 , a fall of 11.4 percent. The resulting compensated decline in taxable income would be TI $\varepsilon_{\mathrm{T}}$ $[d(1-t) /(1-t)]=180,000(1.04)(-.114)=-21340$. Against this must be offset the income effect on taxable income, $(\mathrm{d}$ TI/ dy) $\$ 3160=1264$. The net decline in taxable income is therefore $\$ 20076$, implying a loss of personal income tax revenue at $t=.36$ of $\$ 7227$. There is also a decline of payroll tax revenue of $\$ 181 .^{30}$ The net revenue effect is therefore the difference between the $\$ 3160$ additional revenue that would be collected with no behavioral response and the combined revenue loss of $\$ 7227+\$ 181=7408$, a net revenue loss of $\$ 4248$.

In short, for a taxpayer with initial taxable income of $\$ 180,000$, the rise in the marginal tax rate from 31 percent to 38.9 percent implies a deadweight loss of $\$ 7461$ and a revenue loss of \$4248. Since half of all taxpayers affected by the 1993 tax rate increase had initial taxable incomes below $\$ 180,000$, the majority of those affected by the 1993 tax rate increases experienced a substantially increased deadweight loss while paying a reduced amount of tax!

For taxpayers with high enough income, the $\$ 140,000$ threshold becomes relatively less important and the tax liability actually rises. Consider for example a married couple filing jointly

${ }^{29}$ This assumes that all of the $\$ 180,000$ is wage and salary income and that the excess over $\$ 140,000$ was not previously taxed. These assumptions lead to an overstatement of the favorable revenue effect.

${ }^{30}$ This loss of payroll tax revenue assumes an elasticity of $\varepsilon_{\mathrm{W}}=0.35$ of taxable wages with respect to the net of tax share and an income effect of $\mathrm{dW} / \mathrm{dy}=0.3$. The compensated decline in the taxable wages is therefore $.35 \times .114 \times 180,000=7182$, against which there is an offsetting income effect of $0.3(.079)(40,000)=948$. The taxable wage base therefore declines by 6234 , implying a revenue decline of $.029(6234)=\$ 181$. 
with initial taxable income of $\$ 500,000$. Since the marginal tax rate for such an individual is 0.425 , the increased deadweight loss is $\Delta \mathrm{DWL}=0.5(1.04)\left[(.425)^{2}-(.31)^{2}\right](1.45) 500,000=$ $\$ 31,867$.

The effect of the rate increase on the individual's tax liability is now given by

$$
\mathrm{d} \operatorname{REV}=.079(250,000-140,000)+.115[\mathrm{TI}-250,000]+.396 \mathrm{dTI}+.029 \mathrm{dW}
$$

The first two terms show the revenue increase with no change in behavior while the last two terms show the effect on personal income tax revenue of the decline in taxable income and on the HI payroll tax revenue of a decline in taxable wages. ${ }^{31}$ Thus

$$
\begin{aligned}
& \text { d REV }=8690+.115[\mathrm{TI}-250,000]+.396\left[\{\mathrm{dTI} / \mathrm{d}(1-\mathrm{t})\}_{\mathrm{COMP}}[\mathrm{d}(1-\mathrm{t})]-(\mathrm{d} \mathrm{TI} / \mathrm{dy})\right. \\
& [8690+.115(\mathrm{TI}-250,000)]]+0.029\left[\{\mathrm{dW} / \mathrm{d}(1-\mathrm{t})\}_{\mathrm{COMP}}[\mathrm{d}(1-\mathrm{t})]-(\mathrm{dW} / \mathrm{dy})[8690\right. \\
& +.115(\mathrm{TI}-250,000)]] .
\end{aligned}
$$

With $\{\mathrm{dTI} / \mathrm{d}(1-\mathrm{t})\}_{\mathrm{COMP}}=\mathrm{TI}(1-\mathrm{t})^{-1} \varepsilon_{\mathrm{T}}$ and $\{\mathrm{dW} / \mathrm{d}(1-\mathrm{t})\}_{\mathrm{COMP}}=\mathrm{W}(1-\mathrm{t})^{-1} \varepsilon_{\mathrm{W}}$ the specific parameter values $[\mathrm{TI}=500,000, \mathrm{~d}(1-\mathrm{t}) /(1-\mathrm{t})=-.167$ and $\mathrm{d} \mathrm{TL} / \mathrm{dy}=-0.4$ and $\mathrm{dW} / \mathrm{dy}=-0.3]$ imply $\mathrm{dREV}=$ $37440+0.396[-86840+.4(37440)]+0.029[-28947+.3(37440)]=8468$.

Thus, even for a taxpayer with initial taxable income of $\$ 500,000$, the increase in tax rates from 31 percent to 42.5 percent only increases revenue by $\$ 8468$, or less than one fourth of the no-behavioral-response revenue gain of $\$ 37440$. At the same time, the higher marginal tax rates also increased the deadweight loss on the taxpayer with $\$ 500,000$ of initial taxable income by $\$ 31,867$, an astounding incremental deadweight loss of $\$ 3.76$ cents for every dollar of

\footnotetext{
${ }^{31}$ There is no effect on the rest of the payroll tax revenue because it is only levied on incomes below the level affected by the 1993 tax rate increases. DWL.9 Feb20
} 
revenue.

\section{Microeconomic Estimates with the TAXSIM Model}

This section presents estimates calculated with the NBER's TAXSIM model, a microsimulation model based on a stratified random sample of more than 100,000 individual tax returns provided by the Internal Revenue Service. The estimates include the deadweight loss associated with eliminating the personal tax completely and the incremental deadweight loss and revenue effects of a 10 percent increase in all marginal tax rates and of a repeal of the 1993 tax rate increases

The TAXSIM calculations are based on tax returns for 1991, the most recent available data. These have been adjusted at the NBER to estimated 1994 income levels. The TAXSIM model incorporates the income tax rates and rules as of 1994, including the post-1993 Earned Income Tax Credit rates and the rise in the employer-employee Social Security tax base. The initial marginal personal income tax rate is estimated for each individual on the basis of that individual's taxable income and the 1994 schedule of marginal tax rates. For individuals who are eligible for the Earned Income Tax Credit, the marginal tax rate includes the increase or decrease in the credit per dollar of additional income. ${ }^{32}$

To calculate net marginal tax rates for Social Security, the analysis divides the wage and salary income as reported on each tax return into separate earnings of husbands and wives using

\footnotetext{
${ }^{32}$ To capture the full complexity of the tax rules, the marginal tax rate is calculated by comparing each taxpayer's liability with the initial taxable income to the individual's tax liability if his income rises by $\$ 100$.
}

DWL.9 Feb20 
a method described in Feldstein and Feenberg (1995). Married women are classified as potential retired workers (rather than potential dependent spouses) if their current wage and salary places them at a point in the earnings distribution at which their individual benefits would exceed the benefits to which they would be entitled as a dependent spouse. ${ }^{33}$ The Feldstein-Samwick (1993) estimates of the net present value of future Social Security retirement benefits are then used to adjust the 15.3 percent employer-employee payroll tax rate based on imputed assumptions about age and incomes. ${ }^{34}$

The Deadweight Loss of the Personal Income Tax:

Using individual observations in the TAXSIM program to calculate the deadweight loss of the personal income tax implies a substantially larger value than the deadweight loss implied by the average marginal tax rate. The extent to which the aggregate estimate based on the average marginal tax rate underestimates the more accurate calculation based on individual marginal tax rates depends on the variance of the marginal tax rates. To see the nature of this relation, consider the simplified calculation of the deadweight loss of the income tax based on the elasticity evaluated at the no-tax point on the compensated demand curve, $\varepsilon^{*} \cdot{ }^{35}$ For

${ }^{33} \mathrm{~A}$ married woman is entitled to the higher of her own benefit and 50 percent of her retired husband's benefit. The choice is complicated by such things as the ability of women to claim benefits earlier than their husbands on their own and then shift to the status of dependent beneficiary when their husbands retire. Even those who do not ever claim benefits as a dependent spouse are likely to take the benefit based on husband's income after his death.

${ }^{34}$ These complex net Social Security tax rates for each individual correspond to the simplified assumption of a net present value social security payroll tax of 0.07 in the previous two sections. For each potential tax change, the associated income effect for each individual taxpayer is based on the change that would be induced in that taxpayer's disposable income with no change in taxpayer behavior. 
individual $i$, the deadweight loss is

$$
\mathrm{DWL}_{\mathrm{i}}=0.5 \mathrm{t}_{\mathrm{i}}^{2} \varepsilon^{*} \mathrm{TI}_{\mathrm{i}}
$$

The total deadweight loss based on disaggregated individual data (denoted $\mathrm{DWL}_{\mathrm{D}}$ ) is then

$$
\begin{array}{r}
\mathrm{DWL}_{\mathrm{D}}=0.5 \varepsilon^{*} \Sigma \mathrm{t}_{\mathrm{i}}^{2} \mathrm{TI}_{\mathrm{i}} \\
=0.5 \varepsilon^{*} \mathrm{TI}\left[\mathrm{E} \mathrm{t}_{\mathrm{i}}^{2}\right]
\end{array}
$$

where TI is the aggregate taxable income and $E$ is the expectations operator so that $E t_{i}{ }^{2}$ is the weighted average of the squared marginal rates. In contrast, a deadweight loss calculation based on aggregate data $\left(\mathrm{DWL}_{\mathrm{A}}\right)$ is: $^{36}$

$$
\mathrm{DWL}_{\mathrm{A}}=0.5 \varepsilon^{*} \mathrm{TI}\left[\mathrm{E} \mathrm{t}_{\mathrm{i}}\right]^{2}
$$

Since the weighted variance of the individual marginal tax rates is the difference between the mean of the squares $\left[E t_{i}^{2}\right]$ and the square of the mean $\left[E t_{i}\right]^{2}$, the relation between the aggregate and disaggregated estimates of the deadweight loss is:

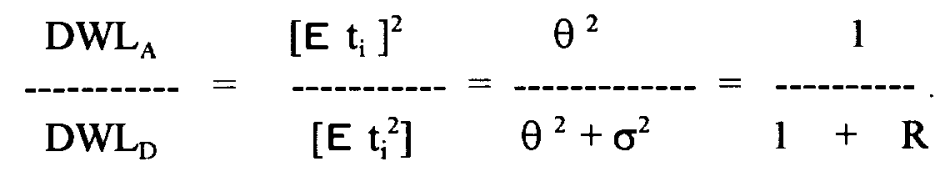

where $\theta=E t_{i}$, the weighted mean of the marginal tax rates and $\sigma^{2}=\left[E t_{i}{ }^{2}\right]-\left[E t_{i}\right]^{2}$, the

${ }^{35}$ This is the original Harberger deadweight loss formula. It differs from the expression in equation 7 by the term (1-t $)^{-1}$ since $t$ is zero at the no-tax point on the demand curve. See Browning (1987).

${ }^{36}$ The deadweight loss calculations of sections 3 and 4 do not use the weighted average of the individual tax rates indicated in equation 19 but approximates this average by the weighted average of the marginal tax rates at the mean taxable income within each broad adjusted gross income class.

DWL.9 Feb20 
weighted variance of those individual marginal tax rates, and $R=\sigma^{2} / \theta^{2}$ is the relative variance.

In the TAXSIM data for 1994, the relative variance is $\mathrm{R}=0.51$, implying that the variance of individual marginal tax rates causes the aggregate measure of the deadweight loss to underestimate the more accurate disaggregated value by 33.8 percent. Applying this ratio to the basic aggregate estimate (in section 3 above) that the deadweight loss of the income tax in 1992 was $\$ 95$ billion implies an adjusted value of $\$ 143$ billion.

The actual disaggregated value for 1994 estimated by TAXSIM was $\$ 181$ billion. The difference between this and the adjusted aggregate value 1992 value of $\$ 143$ billion is the net effect of a variety of factors: the increase in nominal taxable income between 1992 and 1994, the higher marginal tax rates enacted in 1993, and the more complex structure of the microsimulation evaluation of individual marginal tax rates. ${ }^{37}$ The deadweight loss of $\$ 181$ billion represents 32.2 percent of the TAXSIM estimate of $\$ 543$ billion personal income tax revenue for 1994 . This is twelve times the 2.5 percent ratio of deadweight loss to tax revenue estimated in the original Harberger (1964) study.

The TAXSIM estimate of a $\$ 181$ billion deadweight loss ignores the effect of the Social Security payroll tax on the deadweight loss of the income tax. An alternative calculation takes each individual's net Social Security marginal tax rate as given and calculates the total dead weight loss with and without the personal income tax. Treating the personal income tax as

${ }^{37}$ The adjustment factor derived in equation 20 is also an approximation because equation 19 uses $t^{2}$ rather than the $t^{2} /(1-t)$ term derived in equation 7 and used in the actual TAXSIM calculations. Since $t^{2} /(1-t)=t^{2}+t^{3}+t^{4}+\ldots \ldots$, the bias in the aggregate approximation depends also on the higher moments of the distribution of individual marginal tax rates.

DWL.9 Feb20 
incremental in this way implies a substantially larger deadweight loss of $\$ 284$ billion or 52 percent of the personal income tax revenue.

\section{A 10 percent increase in all marginal tax rates}

The TAXSIM calculation indicates that increasing all tax rates by ten percent creates a deadweight loss of $\$ 43$ billion. $^{38}$ Since a ten percent increase in all tax rates would raise $\$ 56$ billion if there were no induced change in taxpayer behavior, this $\$ 43$ billion represents a very high deadweight loss of 78 cents per dollar of potential additional revenue. Moreover, since the higher tax rate causes a decline in taxable income, the increase in revenue is substantially smaller than ten percent of the original personal income tax revenue. The TAXSIM analysis implies that the personal income tax rises by $\$ 26$ billion instead of the $\$ 56$ billion with no behavioral response. The reduced labor supply and the shift away from taxable cash to other types of compensation also reduces the payroll tax revenue by an estimated $\$ 4.1$ billion, so that the total revenue gain from a 10 percent rise in all personal income tax rates is only $\$ 21.4$ billion. Comparing the $\$ 44$ billion deadweight loss to this additional revenue indicates that the incremental deadweight loss per dollar of additional revenue is $\$ 2.06$.

Since the effects on deadweight loss and revenue are symmetric for small increases and decreases in tax rates, a 10 percent across the board reduction in all tax rates would be expected

\footnotetext{
${ }^{38}$ The aggregate estimate of $\$ 23$ billion reported in section 4 underestimates the disaggregated TAXSIM estimate for the same reasons that the overall deadweight loss of the income tax as a whole is underestimated. In order to look at the pure effect of a 10 percent rise in marginal tax rates, the TAXSIM calculation of this tax change is based on a modified 1994 tax law that omits the alternative minimum tax, the earned income tax credit and the credits for child care and for the elderly. These features of the tax law are included in the analysis of repealing the 1993 tax rate increases.
} 
to lose only about $\$ 21$ billion in revenue and to reduce the deadweight loss of the existing tax system by $\$ 44$ billion. Real disposable household incomes (net of the value of foregone leisure) would rise by $\$ 65$ billion or about three dollars per dollar of revenue lost by the government. ${ }^{39}$

Repealing the 1993 tax rate increases

The analysis of section 5 showed that, because of the structure of the tax rate increases enacted in 1993, the higher tax rates were likely to result in little or no additional revenue from most of the affected taxpayers but a large deadweight loss. Although aggregate data did not permit estimating the effect of these tax changes, the TAXSIM calculations confirm the analysis of section 5. Although repealing the 1993 tax rate increases ${ }^{40}$ would cause a loss of personal income tax revenue of $\$ 12.9$ billion if there were no behavioral response, the favorable response of taxable income to the lower marginal tax rates would cause personal income tax revenue to rise by $\$ 4.4$ billion. Returning the ceiling on the HI payroll tax to $\$ 135,000$ causes the revenue

${ }^{39} \mathrm{As}$ a test of the sensitivity of the results to using the estimated elasticity of taxable income of 1.04 for low income groups as well as high income groups, I have evaluated the effects of the 10 percent increase in all personal income tax rates with the compensated and uncompensated elasticities set equal to zero for the 31 million taxpayers with incomes of $\$ 25,000$ or less. Doing so has almost no effect on both tax revenue and the deadweight loss. The tax revenue rises by $\$ 23.6$ billion instead of $\$ 21.4$ billion and the deadweight loss is $\$ 41.4$ billion instead of $\$ 42.8$ billion.

${ }^{40}$ Recall that the 1993 tax legislation raised the marginal income tax rate from 31 percent to 36 percent on taxable incomes between $\$ 140,000$ and $\$ 250,000$ (between $\$ 115,000$ and $\$ 250,000$ for single taxpayers) and to 39.6 percent on taxable income in excess of $\$ 250,000$ and eliminated the previous ceiling of $\$ 135,000$ on the income subject to the 2.9 percent employeremployee HI payroll tax. The current TAXSIM analysis evaluates the effects of reversing these rate increases. The 1993 legislation also changed the alternative minimum tax. That change is not altered in the current calculations, i.e., the analysis measures the effect of reversing the 1993 rate increases with the existing post-1993 alternative minimum tax.

DWL.9 Feb20 
from that tax to fall by $\$ 2.5$ billion. ${ }^{41}$ The net revenue effect of reversing all of the 1993 marginal tax rate increases would therefore be a revenue gain of $\$ 1.9$ billion. The lower marginal tax rates would also reduce the deadweight loss of the tax by a very substantial $\$ 23.2$ billion.

\section{Deferred Consumption and Tax-Favored Saving}

The analysis in this paper has followed the structure of the original 1964 Harberger paper by focussing on the deadweight loss of the income tax in a one-period framework that ignores saving and future consumption. Economists have long recognized that an income tax distorts the choice between current and future consumption by reducing the net rate of return to savers. The problems of estimating the deadweight loss of this distortion at the level of the individual and of the economy are discussed in Little (1951), Harberger (1964), Atkinson and Stiglitz (1980), Sandmo (1985), Feldstein (1977 and 1978) and elsewhere. It would clearly be desirable to extend the analysis of the current paper to deal with these issues in the more general model in which the deadweight loss reflects tax avoidance as well as changes in the supply of labor and capital.

Although such an extension lies beyond the scope of the current paper, I comment now

\footnotetext{
${ }^{41}$ The lower ceiling on the HI payroll tax base would lower overall marginal tax rates and therefore would increase taxable income and personal income tax revenue. This effect is already reflected in the $\$ 4.6$ billion increase in personal income tax revenue. If there were no change in tax rates other than a lowering of the ceiling on the $\mathrm{HI}$ payroll tax base to $\$ 135,000$, the net effect on revenue would actually be positive as the rise in the personal income tax revenue (that results from lowering marginal tax rates from 42.5 percent to 39.6 percent and from 38.9 percent to 36 percent) outweighs the direct loss of $\mathrm{HI}$ payroll tax revenue. The TAXSIM calculation implies that reducing the HI payroll tax base to $\$ 135,000$ would increase total revenue by $\$ 0.9$ billion.
}

DWL.9 Feb20 
on how the analysis of the deadweight loss could be modified to reflect the special role of tax favored saving. The primary tax favored saving arrangements are the exclusion from adjusted gross income of employer contributions to pension plans, of employer/employee contributions to $401 \mathrm{k}$ plans, and of taxpayer contributions to Individual Retirement Accounts. ${ }^{42}$

Tax favored saving is fundamentally different from the other kinds of exclusions and deductions because it involves postponing taxes rather than completely avoiding taxes ${ }^{43}$ The essential structure of the analysis can be represented by assuming that the individual lives for two periods, working in the first and retired in the second. In addition to the exclusions and deductions that represent tax-favored consumption during the first period, the individual has tax favored saving $\mathrm{S}$ in the first period; the distinction between employer pension contributions and individual IRA contributions is irrelevant for this analysis. The amount saved in these special forms is not part of taxable income and grows over time to an amount RS in the retirement period (where $\mathrm{R}=(1+\mathrm{r})^{\mathrm{N}}$ with $\mathrm{r}$ the real rate of interest and $\mathrm{N}$ the time interval between the working period and the retirement period). Consumption in retirement is financed by a combination of the-net-of-tax withdrawal (1-t)RS and an exogenously fixed Social Security

\footnotetext{
${ }^{42}$ There is an extensive literature on these tax-favored saving plans that focuses on the impact of such plans on national saving rather than on the welfare economic issues considered here. See for example Bernheim and Scholz (1993), Engen, Gale and Scholz (1994), Feenberg and Skinner (1993), Gale and Scholz (1994), Poterba, Vendi and Wise (1992 and 1993), and Vendi and Wise (1987 and 1990 ). Feldstein (1992) does consider the deadweight loss in the context of a model in which IRAs affect corporate tax revenue as well as personal income tax revenue.
}

${ }^{43}$ Allowing a deduction or exclusion for saving is equivalent to exempting the return to saving from the tax. To parallel the earlier discussion in this paper, an increase in the net of tax return to saving is best modeled as a reduced tax on future consumption.

DWL.9 Feb20 
pension benefit, B. For simplicity, all of the saving during the first period is in a tax favored form, a reasonable approximation for most individuals.

The individual maximizes a lifetime utility function

$$
\mathrm{U}=\mathrm{U}\left(\mathrm{C}_{1}, \mathrm{C}_{2}, \mathrm{D}, \mathrm{E}, \mathrm{L}\right)
$$

subject to

$$
C_{1}=(1-t)[w(1-L)-E-D-S]
$$

and

$$
C_{2}=(1-t) R S+B
$$

Since the tax-favored saving is done with pretax dollars while the benefits are subject to tax, if the individual's marginal tax rate remains unchanged, the income tax does not alter the relative price of current and future consumption. This is seen clearly if equations 22 and 23 are combined to yield:

$$
C_{1}+R^{-1}\left(C_{2}-B\right)=(1-t)[w(1-L)-E-D]
$$

or

$$
(1+\tau)\left[C_{1}+R^{-1}\left(C_{2}-B\right)\right]=w(1-L)-E-D
$$

The income tax in this more complete model is therefore equivalent to an excise tax at rate $\tau$ on the combination of current consumption and the present value of the future consumption that is financed by tax favored saving. Equation 24 shows that this measure of the relevant ordinary consumption is no longer equal to taxable income minus the tax. To calculate the deadweight loss of the income tax, the taxable income during the working period should be modified by adding the amount of tax favored saving (S) to taxable income (to obtain the adjusted measure on the right hand side of equation 25). The deadweight loss of the income tax DWL.9 Feb20 
and of changes in the income tax depend on the induced change in this adjusted measure of taxable income.

\section{Concluding Comments}

This paper has shown that the deadweight loss of the income tax reflects the induced changes in itemized deductions and in income exclusions as well as the traditional changes in labor supply and saving. More specifically, the analysis shows that the deadweight loss depends on the elasticity of taxable income with respect to the net of tax share. Because this reflects much broader behavior than the traditional elasticity of labor supply, the taxable income elasticity is larger than the traditional labor supply elasticity and the resulting deadweight loss is correspondingly greater. This is borne out by the statistical estimates of the elasticity of taxable income based on the 1986 tax rate reductions. These estimates imply that the deadweight loss per dollar of revenue of using the income tax rather than a lump sum tax is more than twelve times as large as Harberger's classic estimate. If the existing Social Security tax and benefit structure is taken into account, the deadweight loss per dollar of personal income tax revenue is even greater.

The analysis shows that a marginal increase in tax revenue achieved by a proportional rise in all personal income tax rates involves a deadweight loss of two dollars per incremental dollar of revenue. This has important implications for the cost of financing incremental government spending.

The increase in tax rates enacted in 1993 brought no additional revenue and a substantial increase in deadweight loss. More specifically, the TAXSIM calculations imply that repealing DWL.9 Feb20 
the increase in tax rates for high income taxpayers would raise more than $\$ 2$ billion. Moreover, the reduced deadweight loss from that change in tax rates would be $\$ 23$ billion.

The calculations could be improved in a variety of ways. The analysis deals only with a single period of time, ignoring both ordinary saving and tax-favored saving. Similarly, there is no attempt to deal with the deadweight losses that arise from the rules governing the taxation of investments in portfolio assets. Although state income and consumption taxes raise marginal tax rates, they have not been incorporated. It is clear however from the current analysis that the deadweight losses are of a substantial enough magnitude to make further research on these issues a high priority.

February 20, 1995

Cambridge, MA 


\section{References}

Atkinson, A.B. and J. Stiglitz, Lectures in Public Economics, McGraw-Hill Book Company, New York and London, 1980.

Auerbach, Alan, "The Theory of Excess Burden and Optimal Taxation," in Handbook of Public Economics, Vol. 1, A. Auerbach and M. Feldstein (eds.), North-Holland Publishers, 1985.

Auten G. and R. Carroll, "Taxpayer Behavior and the 1986 Tax Reform Act," Treasury Department Office, of Tax Analysis, July 1994.

Ballard, Charles, J. Shoven and J. Whalley, "General Equilibrium Computations of the Marginal Welfare Costs of Taxes in the United States, American Economic Review, pp 128-138, March 1985.

Bernheim D. and J. Scholz, "Private Saving and Public Policy," in Tax Policy and the Economy, James Poterba (ed.), Vol. 7, MIT Press, May 1993.

Browning, Edgar, "On the Marginal Welfare Cost of Taxation," American Economic Review, pp 11-23, March 1987.

Engen, E., W. Gale and J. Scholz, "Do Saving Incentives Work?," Brookings Papers on Economic Activity, pp 85-180, 1994.

Feenberg, D. and J. Skinner, "Sources of IRA Saving," Tax Policy and the Economy, III, pp 25-46, 1989.

Feldstein, M., "Does the U.S. Save Too Little?." American Economic Review, Vol. 45, No. 7, October 1977.

Feldstein, M., "The Welfare Cost of Capital Income Taxation," Journal of Political Economy, Vol. 86, No. 2, Part 2, 1978.

Feldstein, M., "Effects of Tax Based Saving Incentives on National Saving and Government Revenue," NBER Working Paper No. 4021, March 1992, forthcoming in Quarterly Journal of Economics.

Feldstein, M., "The Effect of Marginal Tax Rates on Taxable Income: A Panel Study of the 1986 Tax Reform Act," NBER Working Paper No. 4496, October 1993, forthcoming in Journal of Political Economy. 
Feldstein, M., "Behavioral Responses to Tax Rates: Evidence from TRA86," American Economic Review, May 1995.

Feldstein, M. and D. Feenberg, "The Tax Treatment of Two Earner Families," NBER Working Paper, 1995, forthcoming in M. Feldstein and J. Poterba, Empirical Foundations of Household Taxation.

Feldstein, M. and A. Samwick, "Social Security Rules and Marginal Tax Rates," National Tax Journal, Vol. XLV, No. 1, March 1993.

Gale, W. and J. Scholz, "IRAs and Household Saving," American Economic Review, Vol. LXXXIV, No. 5, December 1994.

Harberger, Arnold, "Taxation, Resource Allocation, and Welfare," in J. Due (ed.), The Role of Direct and Indirect Taxes in the Federal Revenue System, Princeton, NJ: Princeton University Press, 1964.

Hausman, J., "Labor Supply," in How Taxes Affect Economic Behavior, H. Aaron and J. Pechman (eds.), pp 27-72, Washington, D.C.: The Brookings Institution, 1981.

Hausman, J., "Taxes and Labor Supply," in Handbook of Public Economics, Vol. 1, A. Auerbach and M. Feldstein (eds.), North-Holland Publishers, 1985.

Lindsey, Lawrence, "Individual Taxpayer Response to Tax Cuts: 1982-1984, with Implications for the Revenue Maximizing Tax Rate," Journal of Public Economics, Vol. 33, pp 173206, 1987.

Little, I.M.D., "Direct versus Indirect Taxes," Economic Journal, Vol. 61, pp 577-584, 1951.

Navratil, J., " Evidence on Individual Taxpayer Behavior for Panel Tax Return Data", mimeo, 1994.

Poterba, J., S. Venti and D. Wise, "401(k) Plans and Tax Deferred Saving," in Topics in the Economics of Aging, D. Wise (ed.), Chicago, IL: University of Chicago Press, 1992.

Poterba, J., S. Venti and D. Wise, "Do 401(k) Contributions Crowd Out Other Personal Saving?," NBER Working Paper No. 4391, June 1993.

Sandmo, Agnar, "The Effects of Taxation on Savings and Risk Taking," in Handbook of Public Economics, Alan Auerbach and Martin Feldstein (eds.), Vol. 1, pp 265-312, NorthHolland, New York, 1985.

Slemrod, J., "A General Model of the Behavioral Responses to Taxation," mimeo, 1994. 
Stuart, Charles, "Welfare Costs per Dollar of Additional Revenue in the United States," American Economic Review, pp 352-363, June 1984.

Triest, Robert, "The Effect of Income Taxation on Labor Supply when Deductions are Endogenous," Review of Economics and Statistics, 74(1), pp 91-99, February 1992.

U.S. Department of Treasury, Statistics of Income Bulletin, Spring 1994a.

U.S. Department of Treasury, Statistics of Income Bulletin, Fall 1994b.

Venti, S. and D. Wise, "IRAs and Saving," in The Effects of Taxation on Capital Accumulation, M. Feldstein (ed.), Chicago, IL: University of Chicago Press, 1987.

Venti, S. and D. Wise, "Have IRAs Increased U.S. Saving?: Evidence from the Consumer Expenditures Surveys," Quarterly Journal of Economics, Vol. 105, pp 661-698, 1990. 